\title{
Editorial
}

\section{Journal of Innate \\ Immunity}

J Innate Immun 2019;11:109-110

DOI: $10.1159 / 000498950$
Received: February 11, 2019

Accepted: February 11, 2019

Published online: February 26, 2019

\section{Another Brick in the Wall}

Barriers have an important function in the innate immune system as they constitute a physical protection against invading pathogens. Most infections are prevented at surfaces of the body, being eliminated by barrier functions before entering the human host. In this issue of Journal of Innate Immunity a special focus is laid on immune functions based on protection of the host integrity. The functions of the calcareous egg of birds and reptiles and its abilities to mount several arms of host defense when reaching the critical timepoint of hatching is described in a highly interesting review by Hincke et al. [1] in this issue of the journal. Even if most of us have experienced the physical fragility of eggs, there is a plethora of robust innate adaptive immune functions covered by the shell, protecting the developing embryo. Mammals also have to retain strict barriers and at the same time be in close contact with the environment to breathe, absorb nutrients, and interact with commensal bacteria to stay alive. The human skin provides such crucial protection. In an interesting study by Rademacher et al. [2], it is demonstrated that the aryl hydrocarbon receptor is activated during infection with Staphylococcus epidermidis, leading to expression of IL- $1 \alpha$, IL- $1 \beta$, and human $\beta$-defensin-3. The importance of this receptor in immunity is increasingly acknowledged [3]. The airways are the most common port of entry for severe infections. Here, highly specialized epithelial cells and mucins play important roles to keep us healthy [4-6]. However, bacteria can manipulate host defense, thereby creating a niche for survival in an environment that otherwise should be hostile [7-9]. In the gastrointestinal tract, the barriers become even more complex taking into account that water and nutrients are to be taken up to feed the ongoing metabolism and, at the same time, keeping the high load of bacteria out. Graves et al. [10] show that the tapeworm (Hymenolepis diminuta) can inhibit neutrophil chemotaxis by suppressing p 38 MAP kinase activation. This is yet another example on how parasites can disarm host defense to survive. Recently, neuronal alpha-synuclein was demonstrated to be part of gastrointestinal immunity [11]. Interestingly, this molecule may link gastrointestinal immunity to the development of Parkinson's disease [12]. In recent years, it has become more and more apparent that the normal microbiota is important for our health. There is apparently a delicate balance since the microbiota is connected both to modulation of the metabolism and development of neurodegenerative disease $[13,14]$. It is very likely that the microbiota will be a common therapeutic target in the future.

With this, we hope that the readership of Journal of Innate Immunity will enjoy the contents of this issue.

Heiko Herwald, Lund Arne Egesten, Lund

\begin{tabular}{ll}
\hline KARGER & $\begin{array}{l}\text { Ka } 2019 \text { The Author(s) } \\
\text { Published by S. Karger AG, Basel }\end{array}$ \\
E-Mail karger@karger.com & This article is licensed under the Creative Commons Attribution- \\
www.karger.com/jin & $\begin{array}{l}\text { NonCommercial-NoDerivatives 4.0 International License (CC BY- } \\
\text { NC-ND) (http://www.karger.com/Services/OpenAccessLicense). } \\
\text { Usage and distribution for commercial purposes as well as any dis- } \\
\text { tribution of modified material requires written permission. }\end{array}$
\end{tabular}




\section{References}

1 Hincke MT, Da Silva M, Guyot N, Gautron J, McKee MD, Guabiraba-Brito R, et al. Dynamics of structural barriers and innate immune components during incubation of the avian egg: critical interplay between autonomous embryonic development and maternal anticipation. J Innate Immun. 2018, DOI: 10.1159/000493719.

2 Rademacher F, Simanski M, Hesse B, Dombrowsky G, Vent N, Gläser R, et al. Staphylococcus epidermidis activates aryl hydrocarbon receptor signaling in human keratinocytes: implications for cutaneous defense. J Innate Immun. 2018, DOI: 10.1159/ 000492162.

3 Rothhammer V, Quintana FJ. The aryl hydrocarbon receptor: an environmental sensor integrating immune responses in health and disease. Nat Rev Immunol. 2019 Feb. DOI: https://doi.org/10.1038/s41577-019-0125-8.

4 van Putten JP, Strijbis K. Transmembrane Mucins: Signaling Receptors at the Intersection of Inflammation and Cancer. J Innate Immun. 2017;9(3):281-99.
5 Amatngalim GD, Schrumpf JA, Henic A, Dronkers E, Verhoosel RM, Ordonez SR, et al. Antibacterial Defense of Human Airway Epithelial Cells from Chronic Obstructive Pulmonary Disease Patients Induced by Acute Exposure to Nontypeable Haemophilus influenzae: Modulation by Cigarette Smoke. J Innate Immun. 2017;9(4):359-74.

6 Hartl D, Tirouvanziam R, Laval J, Greene CM, Habiel D, Sharma L, et al. Innate Immunity of the Lung: From Basic Mechanisms to Translational Medicine. J Innate Immun. 2018;10(5-6):487-501.

7 Alaridah N, Lutay N, Tenland E, Rönnholm A, Hallgren O, Puthia M, et al. Mycobacteria Manipulate G-Protein-Coupled Receptors to Increase Mucosal Rac1 Expression in the Lungs. J Innate Immun. 2017;9(3):318-29.

8 Riquelme SA, Ahn D, Prince A. Pseudomonas aeruginosa and Klebsiella pneumoniae Adaptation to Innate Immune Clearance Mechanisms in the Lung. J Innate Immun. 2018; 10(5-6):442-54.
9 Fattahi F, Grailer JJ, Lu H, Dick RS, Parlett M, Zetoune FS, et al. Selective Biological Responses of Phagocytes and Lungs to Purified Histones. J Innate Immun. 2017;9(3):300-17.

10 Graves N, Venu VP, Yipp BG, Petri B, Hirota $\mathrm{S}$, Gilleard J, et al. A trypsin-sensitive proteoglycan from the tapeworm Hymenolepis diminuta inhibits murine neutrophil chemotaxis in vitro by suppressing p38 MAP kinase activation. J Innate Immun. 2018, DOI: $10.1159 / 000492303$.

11 Stolzenberg E, Berry D, Yang D, Lee EY, Kroemer A, Kaufman S, et al. A role for neuronal alpha-synuclein in gastrointestinal immunity. J Innate Immun. 2017;9(5):456-63.

12 Labrie V, Brundin P. Alpha-Synuclein to the Rescue: Immune Cell Recruitment by AlphaSynuclein during Gastrointestinal Infection. J Innate Immun. 2017;9(5):437-40.

13 Endres K, Schäfer KH. Influence of Commensal Microbiota on the Enteric Nervous System and Its Role in Neurodegenerative Diseases. J Innate Immun. 2018;10(3):172-80.

14 Heiss CN, Olofsson LE. Gut Microbiota-Dependent Modulation of Energy Metabolism. J Innate Immun. 2018;10(3):163-71. 